efficient to develop a single paediatric rehabilitation resource team to train and advise on head injury.

The report of the working party of the Medical Disability Society on the management of traumatic brain injury virtually ignored services for children. ${ }^{29}$ That omission is further evidence of the need for separate advocacy - a paediatrician in every district to develop and provide services for children with head injuries.

Consultant Paediatrician,

MARION CROUCHMAN

Sheldon Centre,

King's College Hospital,

London SE5 7RN

Manheimer D, Mellinger GD. Personality characteristics of the child accident repeater. Child Der 1967;38:491-513.

2 Rune V. Acute head injuries in children. Acta Paediatr Scand 1970;suppl 209.

3 Department of Health and Social Security. Hospital inpatient enquiry. London: HMSO, 1987.

4 Craft AW, Shaw DA, Cartilidge NE. Head injuries in children. BMF 1972;iv:200-3.

5 Conroy C, Kraus JF. Survival after brain injury. Neuroepidemiology 1988;7:3-22.

6 Kraus JF, Fife D, Conroy C. Pediatric brain injuries: the nature, clinical course, and early outcomes in a defined United States population. Pediatrics 1987;79:501-7.

St James-Roberts J. Neurological plasticity, recovery from brain insult and child development. In Reese HW, Lipsitt LP, eds. Advances in child development and behavior. Vol 14. New York: Academic Press, 1979:255-319.

8 Dillon H, Leopold RL. Children and the post-concussion syndrome. fAMA 1961;175:86-92.

Brink JD, Garrett AL, Hale WR, Woo-Sam J, Nickel VL. Recovery of motor and intellectual function in children sustaining severe head injuries. Dev Med Child Neurol 1970;12:565-71.

10 Mandleberg IA. Cognitive recovery after severe head injury: 3 WAIS verbal and performance IQs s a function of post traumatic amnesia duration and time from injury $\mathcal{I}$ Neurol Neurosur Psvchiatry 1976:39:1001-7.

11 Chadwick $\mathrm{O}$, Rutter $\mathrm{M}$, Brown $\mathrm{G}$. A prospective study of children with head injuries. 2 Cognitive sequelae. Psychol Med 1981:11:49-61.

2 Dencker SJ, Lofving B. A psychometric study of identical twins discordant for closed head injury. Acta Psychiatrica el Neurologica Scandinavica 1958:33:(suppl 122).

13. Mahonev WJ, D'Souza BN, Haller JA, Rogers MC, Epstein MH, Freeman JM. Long term outcome of children with severe head trauma and prolonged coma. Pediatrics 1983;71:756-62.

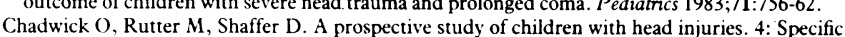
cognitive deficits. Neuropsychologv 1981;3:101-20.

15 Levin HS, Benton AL, Grossman RG. Neurobehavioural consequences of closed head injury. Oxford: Oxford University Press, 1982.

6 Brooks DN. Long and short term memory in head-injured patients. Cortex 1975;11:329-40.

7 Bawden HN, Knights RM, Winogron HW. Speeded performance following head injury in children. F Clin Exp Neuropsychol 1985;7:39-54.

18 Levin HS, Grossman RG, Kelly PJ. Aphasic disorder in patients with closed head injury. F Neurol Neurosurg Psychiatry 1976;39:1062-70.

19 Sarno MT. The nature of verbal impairment after closed head injury. 7 Nerv Ment Dis 1976; 168:685-92

20 Levin HS, Grossman RG, Sarwar M, Meyers CA. Linguistic recovery after closed head injury. Brain Lang 1981;12:360-74.

21 Ewing-Cobbs L, Levin HS, Eisenberg HM. Language functions following closed-head injury in children and adolescents. Fournal of Clinical and Experimental Psychology 1987;9:575-92.

22 Brooks DN. Memory and head injury. 7 Nero Ment Dis 1972;155:350-5.

23 Brooks DN, McKinlay WW. Personality and behavioural changes after severe blunt head injury -a relative's view. I Neurol Neurosurg Psychiatry 1983;46:336-44.

24 Rosen CD, Gerring JP. Head trauma: educational reintegration. London: Taylor and Francis, 1961. Brown G, Chadwick O, Shaffer D, Rutter M, Traub M. A prospective study of children with head injuries in adulthood: 3. Psychiatric sequelae. Psychol Med 1981;11:63-78.

26 Klonoff $\mathrm{H}$, Low MD, Clark C. Head injuries in children: a prospective 5 year follow up. 7 Neuro Neurosurg Psychiatry 1977; 40:1211-9.

27 Robinson OR, Mellor DH. Needs of children with neurosurgical problems. BMJ 1989;298:154.

28 Crouchman MR. Head injury: how the community paediatrician can help. Arch Dis Child 1990;65:1286-7.

29 Medical Disability Society. Report of working party on the management of traumatic brain injury. London: Development Trust for the Young Disabled, 1988.

\title{
New directions in primary biliary cirrhosis
}

\author{
Bile acids look promising
}

Primary biliary cirrhosis has a poor reputation for various reasons. Not least of the problems is that patients do not like being diagnosed as having any sort of cirrhosis because of its implied allegation of alcohol abuse. In fact the condition is not a true cirrhosis at all in the early stages, but suggestions to rename it non-suppurative destructive cholangitis or disappearing bile duct disease, or even (my personal favourite) autoimmune hepatic triaditis have not caught on. The condition is often thought to be rare and invariably unpleasant whereas in reality it is common and often asymptomatic. ${ }^{1-5}$ The only known cure is liver transplantation, which is a reasonable option in those patients with liver failure indicated by pronounced jaundice. ${ }^{67}$

Because primary biliary cirrhosis may be a chronic progressive disabling disease a wide variety of treatments has been assessed. The lack of a proved specific drug cure means that management has often been supportive and aimed at alleviating symptoms. Many drugs have been used in an attempt to suppress the inflammation in the liver, minimise symptoms, and prolong survival.

Glucocorticoids were the first tested. ${ }^{8}$ Initial enthusiasm was tempered by the fact that osteoporotic bone disease worsened during treatment. Recent interest has been shown in using prednisolone, perhaps with adjuvant drugs to reduce the hazards of bone softening, but such treatment is problematical. ${ }^{9}$ The chelating drug penicillamine was tested because of the observation that copper accumulates in the liver of patients with primary biliary cirrhosis and that patients might benefit if this could be cleared. Though there was initial evidence of improved survival, ${ }^{10}$ toxicity led to this line of treatment being abandoned. ${ }^{112}$ Similarly, the opioid antagonist nalmefene has been difficult to use because of side effects. ${ }^{13}$ Oestradiol treatment in women has been tested, but results were variable. ${ }^{1+}$

Immune suppression with azathioprine showed some promise and might lengthen survival, though again the evidence is equivocal. ${ }^{15}{ }^{16}$ Chlorambucil has also been used. ${ }^{17}$ Cyclosporin may be too toxic for use in large doses on its own, causing hypertension and renal impairment, but combined with prednisolone has shown some apparent benefit. ${ }^{18-21}$ Methotrexate has been proposed despite the fact that large doses are known to cause cirrhosis and also acute hepatic failure. ${ }^{22} 23$ The paradoxical approach of using the immune stimulant levamisole did not give encouraging results. ${ }^{24}$ Colchicine as an inhibitor of fibrosis seems a harmless line of treatment which might improve survival, ${ }^{25-28}$ but again long term effects are uncertain and side effects such as blood dyscrasia and peripheral neuropathy are not unknown. ${ }^{29}$

We are therefore faced with a disease that is nasty and treatment that can be nastier. Against this setting a serendipitous discovery opened up a new possibility for treatment. Although coexistent liver disease was said to be a specific contraindication to dissolving gall stones with bile acids, some patients were so treated, and in 1981 Leuschner et al reported biochemical improvements. ${ }^{30}$ At the time there was only mild interest, but in 1987 an uncontrolled study of 15 French patients with primary biliary cirrhosis showed striking reductions in abnormal serum liver function values and good symptom control after treatment with ursodeoxycholic acid. ${ }^{31}$

The philosophy of bile acid treatment is that the hepatocyte affected by autoimmune processes is further damaged because of cholestatic accumulation of endogenous bile acids, such as chenodeoxycholic acid and cholic acid. ${ }^{31-34}$ Partial replacement of normal human bile acids by the hydrophilic and theoretically less harmful ursodeoxycholic acid may be expected to reduce liver inflammation and pruritus. ${ }^{35}$ There may also be direct effects on the immune system, indicated by reduction in abnormal HLA class I expression on hepatocytes. ${ }^{36}$ In addition to these effects there are improvements in abnormal hepatocyte membrane fluidity and some reduction 
in abnormal HLA class II expression on biliary epithelial cells (11th international bile acid meeting, Freiburg im Breisgau, October 1990).

These preliminary findings have been re-examined in various centres in Italy, Germany, Japan, and Britain, and the results of treatment with ursodeoxycholic acid in primary biliary cirrhosis have been found to be generally favourable. ${ }^{3741}$ In uncomplicated symptomatic primary biliary cirrhosis treatment produces an almost uniform and striking reduction in abnormal serum enzyme activities, and there is some evidence too of a reduction in the number of inflammatory cells in the liver. What impresses the patients is symptom control: diarrhoea resolves, pruritus improves or disappears, and malaise and abdominal discomfort lessen. Ursodeoxycholic acid may also have benefits in other liver conditions such as chronic active hepatitis, biliary atresia, primary sclerosing cholangitis, liver transplant failure, cystic fibrosis, and even non-specific (probably viral) raised aminotransferase activities in rejected blood donors. ${ }^{2-49}$ Calcification of gall stones is the only convincingly shown potentially adverse effect of treatment. ${ }^{50}$

Is ursodeoxycholic acid a rose without a thorn? The best dose is not clear ${ }^{38+1}$ but may be in the range used for gall stone dissolution (10 mg/kg.a day, or $750 \mathrm{mg}$ daily for simplicity). Such a dose has been widely used for various indications over 10 years without serious problems. Treatment is costly $(£ 1 \cdot 60$ a day for $750 \mathrm{mg}$ in Britain) and will need to be prolonged. Some patients with advanced primary biliary cirrhosis may fail to respond or even deteriorate during treatment. ${ }^{51-54}$ No beneficial effect is expected on complications such as variceal bleeding, encephalopathy, or bone disease. There has been some anxiety about the effect of increasing faecal excretion of ursodeoxycholic acid, and more importantly its metabolites, on the colonic mucosa. ${ }^{55.57}$ This hypothetical problem may not be relevant in the treatment of primary biliary cirrhosis as ursodeoxycholic acid is more acceptable than the alternative specific drug treatment. It will probably earn a place in management.

The exact role of ursodeoxycholic acid in primary biliary cirrhosis has become even more topical with the unequivocal demonstration that asymptomatic patients have a very much reduced life expectancy. ${ }^{355859}$ Any safe treatment that improved longevity would clearly have a role. Ursodeoxycholic acid is not yet known to improve survival in primary biliary cirrhosis, though the evidence on improved liver function is highly suggestive and the outlook hopeful. What all this shows is an urgent need for a properly controlled large trial to see whether these general histological, biochemical, and symptomatic benefits of treatment with ursodeoxycholic acid are associated with a diminished mortality in early primary biliary cirrhosis.

Consultant Physician,

M C BATESON

General Hospital,

Bishop Auckland,

County Durham DL14 6AD

1 Myszor M, James OFW. The epidemiology of primary biliary cirrhosis in north-east England: an increasingly common disease? $Q$ f Med 1990;276:377-85.

2 Danielsson A, Boqvist L, Uddenfeldt P. Epidemiology of primary biliary cirrhosis in a defined rural population in the northern part of Sweden. Hepatology 1990;11:458-64.

Nyberg A, Löö L. Primary biliary cirrhosis: clinical features and outcome, with special reference to asymptomatic disease. Scand f Gastroenterol 1989;24:57-64.

reference to asymptomatic disease. Scand F Gastroenterol 1989;24:57-64.
4 Brenard R, Degos F, Degott C, Lassoued K, Benhamou JP. La cirrhose biliaire primitive: modes Brenard R, Degos F, Degott C, Lassoued K, Benhamou JP. La
actuels de présentation. Gastroenterol Clin Biol 1990;4:307-12.

5 Mitchison HC, Lucey MR, Kelly PJ, Neuberger JM, Williams R, James OFW. Symptom development and prognosis in PBC: a study in 2 centres. Gastroenterology 1990;99:778-84.

6 Markus BH, Dickson ER, Grambsch PM, et al. Efficacy of liver transplantation in patients with primary biliary cirrhosis. $N$ Engl f Med 1989;320:1709-13

7 Neuberger J, Gunson BM, Buckels JAC, Elias E, McMaster P. Referral of patients with PBC for liver transplantation. Gut 1990;31:1069-72.

8 Carman CT, Giansiracusa JE. Effect of steroid therapy on the clinical and laboratory features of primary biliary cirrhosis. Gastroenterology 1955;28:193-215.

9 Mitchison HC, Bassendine MF, Malcolm AJ, Watson AJ, Record CO, James OFW. A pilot, double-blind, controlled 1 year trial of prednisolone treatment in PBC: hepatic improvement but greater bone loss. Hepatology 1989;10:420-9.

10 Epstein O, Jain S, Lee RG, et al. D-penicillamine treatment improves survival in PBC. Lancet $1981 ; \mathrm{i}: 1275-9$.

11 Neuberger J, Christensen E, Portman B, et al. Double-blind controlled trial of penicillamine in PBC. Gut 1985;26:114-9.

12 Bodenheimer HC, Schaffner F, Sternlieb I, Killon FM, Vernace S, Pezzullo J. A prospective clinical trial of D-penicillamine in the treatment of PBC. Hepatology 1985;5:1139-42.

13 Thornton JR, Losowsky MS. Opioid peptides and primary biliary cirrhosis. BMF 1988;297: $1501-4$.

14 Guattery JM, Faloon WW. Effect of estradiol upon serum enzymes in PBC. Hepatology 1987;7: 737-42.

15 Christensen E, Neuberger J, Crowe J, et al. Beneficial effect of azathioprine and prediction of prognosis in PBC. Gastroenterology 1985;89:1084-91.

16 Heathcote J, Ross A, Sherlock S. A prospective controlled trial of azathioprine in primary biliary cirrhosis. Gastroenterology 1976;70:656-60.

17 Hoofnagle JH, Davis GL, Schafer DF, et al. Randomised trial of chlorambucil for primary biliary cirrhosis. Gastroenterology 1986;91:1327-34.

8 Wiesner RH, Ludwig J, Lindor KD, et al. A controlled trial of cyclosporin in the treatment of primary biliary cirrhosis. $N$ Engl F Med 1990;322:1419-24.

19 Lie TS, Preissinger H. Successful treatment of primary biliary cirrhosis with ciclosporine. Deutsche Medizinische Wochenschrift 1990;115:740-2.

20 Minuk GY, Bohme CE, Burgess E, et al. Pilot study of cyclosporin A in patients with symptomatic primary biliary cirrhosis. Gastroenterology 1988;95:1356-63.

21 Beukers R, Schalm SW. Effect of cyclosporine and cyclosporine plus prednisolone in primary biliary cirrhosis. Transplant Proc 1988;20:340-3.

22 Clegg DO, Furst DE, Tolman KG, Pogue R. Acute reversible hepatic failure associated with methotrexate treatment of rheumatoid arthritis. F Rheumatol 1989;16:1123-6.

23 Kaplan MM, Knox TA, Arora S. Primary biliary cirrhosis treated with low-dose oral pulse methotrexate. Ann Intern Med 1988;109:429-31.

24 Hishon S, Tobin G, Ciclitira PJ. A clinical trial of levamisole in primary biliary cirrhosis. Postgrad Med F 1982;58:701-3.

25 Kaplan MM, Alling DW, Zimmerman $\mathrm{HJ}$, et al. A prospective trial of colchicine for primary biliary cirrhosis. N Engl F Med 1986;315:1448-54.

26 Kershenobich D, Vargas F, Garcia-Tsao G, Tamayo RP, Rojkind M. Colchicine in the treatment of cirrhosis of the liver. N Engl f Med 1988;318:1709-13.

27 Bodenheimer H, Schaffner F, Pezzullo J. Evaluation of colchicine therapy in primary biliary cirrhosis. Gastroenterology 1988;95:124-9.

28 Warnes TW, Smith A, Lee FI, Haboubi NY, Johnson P, Hunt L. A controlled trial of colchicine in primary biliary cirrhosis. Trial design and preliminary report. $f$ Hepatol 1987;5:1-7.

29 Finklestein M, Goldman L, Grace ND, Foely M, Randall N. Granulocytopenia complicating colchicine therapy for primary biliary cirrhosis. Gastroenterology 1987;93:1231-5.

30 Leuschner $\mathrm{U}$, Leuschner $M$, Hübner $\mathrm{K}$. Gallstone dissolution in patients with chronic active hepatitis. Gastroenterology 1981;80:A1208.

31 Poupon R, Poupon RE, Calmus Y, Ballet F, Darnis F. Is ursodeoxycholic acid an effective treatment for primary biliary cirrhosis? Lancet 1987; i:834-6.

32 Krol T, Kitamura T, Miyai K, Hardison W. Tauroursodeoxycholate reduces ductular proliferation and portal inflammation in bile-duct-ligated hamsters. Hepatology 1983;80:A881.

33 Miyazaki $\mathrm{K}$, Nakayama F, Koga $\alpha$. Effect of chenodeoxycholic and ursodeoxycholic acids on isolated adult human hepatocytes. Dig Dis Sci 1984;29:1123-30.

34 Batta AK, Arora R, Salen G, Tint GS, Eskreis D, Katz S. Characterisation of serum and urinary bile acids in patients with primary biliary cirrhosis by gas-liquid chromatography-mas spectrometry: effect of ursodeoxycholic acid treatment. $f$ Lipid Res 1989;30:1953-62.

35 Hofmann AF, Popper H. Ursodeoxycholic acid for primary biliary cirrhosis. Lancet 1987;ii:398-9.

6 Calmus V, Gane P, Rouger P, Poupon R. Expression of class I and class II major histocompatibility complex molecules in primary biliary cirrhosis; effect of UDCA. Hepatology 1989;11:12-5. Bateson MC, Ross PE, Diffey BL. Ursodeoxycholic acid in primary biliary cirrhosis. Lancet 1989;i:898-9.

38 Podda M, Ghezzi C, Battezzati PM, et al. Effect of different doses of ursodeoxycholic acid in chronic liver disease. Dig Dis Sci 198§; 34:59-65S.

39 Leuschner U, Fischer $\mathrm{H}$, Kurtz W, et al. Ursodeoxycholic acid in primary biliary cirrhosis: results of a controlled double-blind trial. Gastroenterology 1989;97:1268-74.

40 Matsuzaki Y, Tanaka N, Osuga T, et al. Improvement of biliary enzyme levels and itching as a result of long-term administration of ursodeoxycholic acid in primary biliary cirrhosis. Am $\mathcal{f}$ Gastroenterol 1990 85:15-23.

41 Bateson MC. Ursodeoxycholic acid $750 \mathrm{mg}$ versus $1000 \mathrm{mg}$ daily for primary biliary cirrhosis. Hepatology Rapid Literature Review 1990;20:IX-X.

42 Stiehl A, Raedsch R, Kommerell B. The effect of UDCA in primary sclerosing cholangitis. A comparison to primary biliary cirrhosis. Gastroenterology 1988;94:A595

43 Podda M, Ghezzi C, Battezzati PM, Crosignani A, Zuin M, Roda A. Effects of ursodeoxycholic acid and taurine on serum liver enzymes and bile acids in chronic hepatitis. Gastroenterology 1990;98:1044-50.

44 Leuschner U, Leuschner M, Sieratzki ML, Kurtz W, Hübner K. Gallstone dissolution with ursodeoxycholic acid in patients with chronic active hepatitis and two years follow-up. Dig Dis $S c i$ 1985;30:642-9.

45 Ullrich D, Rating D, Schröter W, Hanefeld F, Bircher J. Treatment with ursodeoxycholic acid renders children with biliary atresia suitable for liver transplantation. Lancet 1987;ii:1324.

46 Persson H, Friman S, Schersten T, Svanvik J, Karlberg I. Ursodeoxycholic acid for prevention of acute rejection in liver transplant recipients. Lancet 1990;336:52-3.

47 Bellentani S, Tabarroni G, Barchi T, et al. Effect of ursodeoxycholic acid treatment on alanine amino-transferase and $\gamma$-glutamyltranspeptidase serum levels in patients with hypertransamino-transferase and $\gamma$-glutamyltranspeptidase serum levels in patients with
aminasemia. Results from a double-blind controlled trial. $\mathcal{F}$ Hepatol 1989;8:7-12.

48 Nakagawa $M$, Colombo $C$, Setchell KDR. Comprehensive study of biliary bile acid composition of patients with cystic fibrosis and associated liver disease before and after UDCA administration. Hepatology 1990;12:322-34.

49 Hayashi H, Higuchi T, Khimiya A, Hishida N, Sakamoto N. Asymptomatic primary sclerosing cholangitis treated with UDCA. Gastroenterology 1990;99:533-5.

50 Bateson MC, Maudgal DP, Trash DB, Northfield TC, Bouchier IAD. Gall stone calcification caused by ursodeoxycholic acid. BMF 1981;283:645-6.

51 Kneppelhout JC, Mulder CJJ, van Henegouwen GP, de Vries RA, Brandt KH. Effect of UDCA on liver function and pruritus in primary biliary cirrhosis. Gastroenterology 1990;98:A598.

52 O'Brien CB, Senior JR, Sternlieb JM, et al. Ursodiol treatment of primary biliary cirrhosis. Gastroenterology 1990;98:617.

53 Lotterer E, Stiehl A, Raedsch R, Foelsch UR, Bircher J. Ursodeoxycholic acid in primary biliary cirrhosis: no evidence for toxicity in the stages I to III. J Hepatol 1990;10:284-90.

54 Vogel W, Kathrein H, Judmaier G, Braunsteiner $H$. Deterioration of primary biliary cirrhosis during treatment with ursodeoxycholic acid. Lancet 1988; $1: 1163$.

55 Hill M. Neoplasms: epidemiology and aetiology. Current Opinion in Gastroenterology 1988;4:3-8.

56 Simanowski UA, Seitz HK, Czygan P, et al. Chronic ursodeoxycholic acid- and chenodeoxycholic acid-feeding-induced changes of colon mucosal cell proliferation in rats. fNCI 1987;79:163-6.

57 Owen RW, Dodd $M$, Thompson MH, Hill MJ. Faecal steroid loss in healthy subjects during short term treatment with ursodeoxycholic acid. F Steroid Biochem 1987;26:503-7.

58 Rydning A, Schrumpf E, Abdelnoor M, Elgio K, Jenssen E. Factors of prognostic importance in primary biliary cirrhosis. Scand f Gastroenterol 1990;25:119-26.

59 Balasubramaniam K, Grambsch PM, Wiesner RH, Lindoe KD, Dickson ER. Diminished survival in asymptomatic primary biliary cirrhosis: a prospective study. Gastroenterology 1990;98: $1567-71$ 